\title{
Characterisation of Several Rye Cultivars with Respect to Arabinoxylans and Extract Viscosity
}

\author{
Hans-Ulrich Jürgens, Gisela Jansen \& Christina B. Wegener \\ Institute for Resistance Research and Stress Tolerance, Julius Kühn-Institute \\ Federal Research Centre for Cultivated Plants, D-18190 Sanitz, Germany \\ E-mail: christina.wegener@jki.bund.de
}

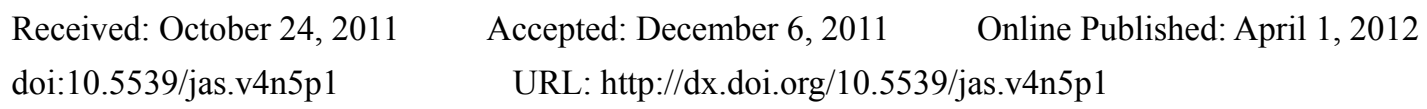

\begin{abstract}
Arabinoxylans are considered as the major limiting factor for use of rye in animal feeding. In this study, four selected winter rye cultivars were grown at nine locations and tested for arabinoxylans including total (TAX), soluble (SAX) and insoluble fractions (IAX), extract viscosity, falling numbers and crude protein contents. Amounts of TAX ranged on average between 89 and $103 \mathrm{~g} / \mathrm{kg}$ wholemeal flour, and the extract viscosity between 2.6 and $5.1 \mathrm{cSt}$. The extract viscosity was significantly correlated with falling numbers and all three arabinoxylan fractions. Arabinoxylan contents and extract viscosity were influenced by the rye genotype. The anthocyanin free hybrid cultivar Helltop combined reduced TAX, SAX and IAX levels with low extract viscosity and high crude protein contents and seems to be more suitable for use in animal feeding than the other three cultivars tested in this respect.
\end{abstract}

Keywords: Rye, Arabinoxylans, HPLC, Extract viscosity, Falling numbers, Animal feeding, Crude proteins

Abbreviations: TAX, total arabinoxylans; SAX, water-soluble arabinoxylans; IAX, insoluble arabinoxylans; dm, dry matter; rpm, rotation per minute; HPLC, high pressure liquid chromatography; ASER, anthranilic acid ethyl ester reagent; ISTD, internal standard solution; THF, tetrahydrofuran

\section{Introduction}

Rye (Secale cereale L.) as one of the most important cereal crops in Central Europe is closely related to wheat however it has several economic advantages (Allen, 2002). Rye is more tolerant than wheat to frost and drought and it can grow on wide range of soil types including poor, sandy soils. In addition, rye has some nutritional benefits over wheat, since its content of minerals, lysine and dietary fibre is higher (Allen, 2002). Besides starch which comprises about $65 \%$ of the dry matter $(\mathrm{dm})$, dietary fibre is the most abundant component in whole-grain rye with about 17\% of dm (Bengtsson and Aman, 1990). Major non-starch polysaccharides (NSP) are arabinoxylans with about $8 \%$ of $\mathrm{dm}$. They primarily consist of the two sugars L-arabinose and D-xylose (Boros et al., 1993) and represent about 55\% of total NSP in rye grains (Bengtsson and Aman, 1990; Knudsen and Laerke, 2010). Arabinoxylans are major components of the rye endosperm cell walls (Vinkx and Delcour, 1996), and consist of a linear backbone of (1-4)- $\beta$-D-xylopyranose residues partly substituted with $\alpha$-L-arabinofuranosyl residues (Hansen et al., 2003; Bengtsson et al., 1992). The arabinoxylan content in rye is higher than that found for barley and wheat (Nyström et al., 2008). Rye is an important source of dietary fibre in human diet (Hansen et al., 2003; Anonymus, 2011) and regarded as a healthy food that can reduce the risk of cancers, coronary heart diseases and diabetes (Dongowski, 2007; Garcia et al., 2007; Linko and Adlercreutz, 2005; Nyström et al., 2008). In Europe rye is mainly cultivated as bread grain (Bengtsson et al., 1992). Its arabinoxylans improve the baking quality (Saastamoinen et al., 1989; Vinkx and Delcour, 1996), and preserve freshness and sensoric properties of bread through the formation of starch-arabinoxylan complexes (Jankiewicz and Michniewicz, 1987).

In Germany, about half of the rye grains harvested annually are used for animal feeding (Anonymus, 2011). However, the high level of antinutritive substances in rye such as NSP can reduce its digestibility and feeding quality, particularly for mongastric animals (Antoniou et al., 1981). Above all, these are arabinoxylans forming highly viscous solutions in water (Bengtsson and Aman, 1990) associated with negative effects on the food uptake and growth reduction. Hence, arabinoxylans are considered to be the major limiting factor for unrestricted use of rye as feeding component (Antoniou et al., 1981). Water-soluble and insoluble fractions of arabinoxylans 
from rye incorporated in a wheat based diet caused growth depression of chicken by 20 and $55 \%$, respectively (Antoniou et al., 1981). In order to open new ways of using rye in animal feed rye cultivars with diminished arabinoxylan contents and low extract viscosities are needed, and rye breeding should pay more attention to this topic in the future. But, this requires efficient methods for the assay of arabinoxylans accumulated in rye grains with a high throughput of samples.

The aim of the present work was to evaluate German winter rye cultivars for parameters that influence the feeding quality of rye such as arabinoxylans comprising (i) total, (ii) water-soluble and (iii) insoluble fractions as well as extract viscosity, falling numbers and crude protein contents.

\section{Materials and Methods}

\subsection{Rye Samples}

The three hybrid winter rye cultivars Helltop (Year of registration, 2009), Minello (2008), Visello (2006) and the population variety Conduct (2006) were grown in field plots at nine locations, i.e. Gülzow, Neuhof, Borwede, Hude, Hamerstorf, Rembserhof, Mayen-Rosenhof, Vipperow and Bornhof, situated all in different districts of the four German states Mecklenburg-Western Pomerania, Lower Saxony, Rhineland-Palatinate and Bavaria. The experiments were carried out in 2010 under uniform agronomic management (Fertilizer, herbicides etc.). The locations were distributed from the North to the South of Germany, and the soil types varied from sandy soil over loamy sand or sandy loam to silty loam. The long term average rainfall ranged from $549 \mathrm{~mm}$ at Bornhof to $820 \mathrm{~mm}$ at Rembserhof.

After harvest, grain samples of about $250 \mathrm{~g}$ per rye cultivar were randomly taken and analysed in the laboratory of the Institute for Resistance Research and Stress Tolerance, Experimental Station for Potato Research, Groß Lüsewitz situated in Mecklenburg-Western Pomerania, Germany. The rye grains were ground in a Laboratory mill 3100 (Perten Instruments, Hamburg, Germany) to pass a $0.8 \mathrm{~mm}$ sieve, and the wholemeal flour was used for the analyses as detailed below. All wholemeal samples revealed a dry matter content of about $88 \%$ and were stored at room temperature until analyses.

\subsection{Assay of Total, Soluble and Insoluble Arabinoxylans}

Chemicals and standard solutions: Anthranilic acid ethyl ester, dimethyl sulfoxide (DMSO), sodium cyanoborohydride, sodium hydroxide solution $(50 \%, \mathrm{w} / \mathrm{v})$, arabinose, xylose, galactose, glucose, rhamnose and fucose were supplied by Sigma-Aldrich (Taufkirchen, Germany). Sulfuric acid (1 mol/l), glacial acetic acid, sodium azide, formic acid and methanol were obtained from Merck (Darmstadt, Germany). Tetrahydrofuran (THF) was supplied by Lab Scan, (Gliwice, Polen) and 2-deoxy-D-glucose by Acros Organics (Geel, Belgium). Anthranilic acid ethyl ester reagent (ASER): $40 \mathrm{mg}$ of sodium cyanoborohydride were dissolved in $700 \mu 1$ DMSO, before $55 \mu \mathrm{l}$ of anthranilic acid ethyl ester and $300 \mu \mathrm{l}$ of glacial acetic acid were added. Internal standard solution (ISTD): $40 \mathrm{mg}$ of 2-deoxy-D-glucose were dissolved in $1 \mathrm{ml}$ of deionized water. Sugar standards: 50 $\mathrm{mg}$ of arabinose, $50 \mathrm{mg}$ of xylose, $10 \mathrm{mg}$ of galactose, $1000 \mathrm{mg}$ of glucose, $10 \mathrm{mg}$ of rhamnose and $10 \mathrm{mg}$ of fucose were dissolved in $10 \mathrm{ml}$ of deionized water. For the assay of arabinoxylans the hydrolysis of rye samples was carried out according to Fengler and Marquardt (1988a) and the generated monosaccharides were fluorescent labelled following the method detailed by Bigge et al. (1995). Appropriate dilutions of the sugar standard were prepared, and $1 \mathrm{ml}$ of each dilution was supplemented with $100 \mu \mathrm{l}$ of ISTD reagent and thoroughly mixed. $10 \mu \mathrm{l}$ of this solution were mixed with $100 \mu \mathrm{l}$ of ASER and heated in a thermo-block at $80{ }^{\circ} \mathrm{C}$ for $2 \mathrm{~h}$. After derivatization, $1.9 \mathrm{ml}$ of deionized water containing $1 \mathrm{mmol} / \mathrm{l}$ sodium azide were added, the solution was mixed and centrifuged at $20000 \times \mathrm{g}$ for $20 \mathrm{~min}$ at $4^{\circ} \mathrm{C}$. The supernatant was used for $\mathrm{HPLC}$ analyses as described below.

In order to analyse total amounts of arabinoxylans (TAX) $400 \mathrm{mg}$ of rye wholemeal flour were transferred into a $15 \mathrm{ml}$ Falcon-tube, and suspended in $10 \mathrm{ml}$ of $1 \mathrm{~mol} / 1$ sulfuric acid using a laboratory shaker. The sample was hydrolyzed at $99{ }^{\circ} \mathrm{C}$ for $2 \mathrm{~h}$ on a thermomixer (Eppendorf, Wesseling-Berzdorf, Germany), cooled, and an aliquot of $1 \mathrm{ml}$ was supplemented with $100 \mu \mathrm{l}$ of ISTD solution, mixed and centrifuged at $20000 \times \mathrm{g}$ for $20 \mathrm{~min}$ at $4{ }^{\circ} \mathrm{C}$. $10 \mu \mathrm{l}$ of the supernatant were mixed with $100 \mu \mathrm{l}$ of ASER reagent, and heated in a thermo-block at $80{ }^{\circ} \mathrm{C}$ for $2 \mathrm{~h}$. After derivatization, $1.9 \mathrm{ml}$ of deionized water containing $1 \mathrm{mmol} / \mathrm{l}$ sodium azide were added, the solution was mixed and centrifuged at $20000 \times \mathrm{g}$ for $20 \mathrm{~min}$ at $4^{\circ} \mathrm{C}$. The supernatant was used for $\mathrm{HPLC}$ analyses.

The extract samples for measurement of soluble arabinoxylans (SAX) were prepared according to Boros et al. (1993). $2 \mathrm{~g}$ of rye wholemeal flour were suspended in $20 \mathrm{ml}$ of deionized water and shaken for $1 \mathrm{~h}$ at $20^{\circ} \mathrm{C}$. The 
suspension was centrifuged at $12000 \times \mathrm{g}$ for $10 \mathrm{~min}$ at $5{ }^{\circ} \mathrm{C}$. The supernatant was used for the assay of soluble arabinoxylans, and in addition for measurement of the extract viscosity as detailed below.

For the analyses of SAX, $1 \mathrm{ml}$ of the extract sample was supplemented with $0.5 \mathrm{ml}$ of $3 \mathrm{~mol} / 1 \mathrm{of}_{2} \mathrm{SO}_{4}$, mixed and hydrolysed at $99^{\circ} \mathrm{C}$ for $2 \mathrm{~h}$ on an Eppendorf-thermomixer. The hydrolysate was cooled, and supplemented with $50 \mu \mathrm{l}$ of ISTD reagent, mixed and then centrifuged at $20000 \times \mathrm{g}$ for $20 \mathrm{~min}$ at $4{ }^{\circ} \mathrm{C} .20 \mu \mathrm{l}$ of the supernatant were supplemented with $100 \mu \mathrm{l}$ ASER reagent and heated in a thermo-block at $80{ }^{\circ} \mathrm{C}$ for $2 \mathrm{~h}$. Afterwards, the sample was supplemented with $1.9 \mathrm{ml}$ of water containing $1 \mathrm{mmol}$ of $\mathrm{NaN}_{3}$, mixed and centrifuged as detailed before. The supernatants were used for the HPLC assay performed in a HPLC-system consisting of a PU 980 pump, a gradient mixer LG 1580 (both from Jasco, Gross-Umstadt, Germany), a fluorescence detector RF-10AXL (EX, $340 \mathrm{~nm}$; EM, $420 \mathrm{~nm}$; Shimadzu, Duisburg, Germany) and an autosampler 465 (Kontron Instruments, Neufahrn, Germany). Sugar separation was carried out on a Synergi Polar-RP 80A column $(150 \times 3 \mathrm{~mm} ; 4.0 \mu \mathrm{m}$; Phenomenex, Aschaffenburg, Germany) equipped with an RP pre-column, at a flow rate of $0.7 \mathrm{ml} / \mathrm{min}$. The injection volume was $10 \mu \mathrm{l}$ for TAX and $20 \mu \mathrm{l}$ for SAX. The column temperature was maintained at $25^{\circ} \mathrm{C}$.

Solvent (A): $900 \mathrm{ml}$ of $0.1 \mathrm{~mol}$ of formic acid adjusted to $\mathrm{pH} 3.85$ with $\mathrm{NaOH}(50 \%$, w/v) were mixed with 200 $\mathrm{ml}$ of THF. Solvent (B): $200 \mathrm{ml}$ of formic acid (pH 3.85) were mixed with $800 \mathrm{ml}$ of methanol. The following gradient was used: 0 - $13 \mathrm{~min}, 100 \% \mathrm{~A} ; 13-16 \mathrm{~min}, 0-20 \% \mathrm{~B} ; 16-18 \mathrm{~min}, 20-100 \% \mathrm{~B} ; 18-22 \mathrm{~min}, 100 \% \mathrm{~B}$; $22-24 \mathrm{~min}, 0-100 \% \mathrm{~A} ; 24-27 \mathrm{~min}, 100 \% \mathrm{~A}$. Analyses of arabinoxylans were performed in duplicate with standard deviation (S.D.) $\leq 4 \%$. Software Shimadzu Class VP was used for data analyses. The amounts of arabinose and xylose present in the extract samples were summarized for expression of TAX and SAX, respectively.

In order to determine insoluble arabinoxylans (IAX) an indirect method was used, i.e. contents of IAX were calculated as differences between total and water-soluble arabinoxylans (IAX=TAX-SAX). Amounts of total, soluble and insoluble arabinoxylans were expressed in grams per kilograms of rye wholemeal flour.

\subsection{Assay of Extract Viscosity}

Extract samples used for the viscosity assay according to Boros et al. (1993) were prepared as described for measurement of SAX. Aliquotes of the water-extract samples were applied to a ViscoSystem AVS 350 instrument (Schott-Geräte, Ludwigshafen, Germany) equipped with a capillary viscosimeter, and connected with a ViscoDoser AVS 20 piston buret (Schott-Geräte) which enabled an automated viscosity assay. The latter was carried out at $30{ }^{\circ} \mathrm{C}$, using an extract volume of $2 \mathrm{ml}$ per assay. Measurements of extract viscosity were performed in duplicate with S.D. $\leq 5 \%$. The instrument software package (Win Visco) was used for data analyses, and the viscosity was expressed in centistokes (cSt).

\subsection{Assay of Falling Numbers}

The Hagberg Falling Number (HFN) was measured in a falling number system FN 1400 (Perten Instruments $\mathrm{GmbH}$, Hamburg, Germany) according to the method described by Barnard (2001) using $7.0 \mathrm{~g}$ rye wholemeal flour per assay and an extract volume of $25 \mathrm{ml}$. Falling numbers were expressed in seconds (s). All measurements were performed in duplicate with standard deviation $\leq 5 \%$.

\subsection{Assay of Crude Proteins}

The concentration of crude proteins was determined according to Kjeldahl (conversion factor, 6.25) using $0.5 \mathrm{~g}$ of rye wholemeal flour for each assay. Measurements were performed in duplicate with standard deviation $\leq 5 \%$. Amounts of crude protein were expressed in grams per kilograms of wholemeal flour.

\subsection{Statistical Analysis}

Differences in TAX, SAX, IAX, extract viscosity, falling numbers and crude protein contents between the four winter rye cultivars were tested using the SAS 9.2 statistical package (PROC GLM, Tukey-test, SAS Institute Inc., Cary, NC, USA). In this case, the locations were arranged in nine replications. In order to test the differences between the locations, the rye cultivars were arranged in four replications. $\mathrm{P}<0.05$ was considered significant.

Correlations (Pearson) between individual quality parameters were calculated using the SAS 9.2 statistical package (Procedure CORR). Data obtained for the four rye cultivars and nine locations were involved in the calculations $(\mathrm{n}=36)$. $\mathrm{P}<0.05$ was regarded to be statistically significant. 


\section{Results}

The acid hydrolysis of rye samples according to Fengler and Marquardt (1988a) combined with a fluorescent labelling of the released monosaccharides (Bigge et al. 1995) and a HPLC assay enabled a good separation of the individual sugars as indicated by the chromatogram presented in figure 1. Separation of arabinose and xylose as the two major sugars of arabinoxylans on a reverse phase column could be improved through supplementation of tetrahydrofuran to solvent (A) instead of methanol or acetonitrile generally used by other authors, e.g. Known \& $\operatorname{Kim}(1995)$.

\subsection{Total, Soluble and Insoluble Arabinoxylans}

Contents of total arabinoxylans ranged on average between $89 \mathrm{~g} / \mathrm{kg}$ for cultivar Helltop and $103 \mathrm{~g} / \mathrm{kg}$ for Minello (Table 1). Helltop revealed the lowest amounts of TAX in grains derived from Rembserhof with a value of 82 $\mathrm{g} / \mathrm{kg}$. At all nine locations this cultivar had less TAX than Conduct, Minello and Visello, which all three displayed their lowest TAX contents at Mayen-Rosenhof with a value of 91,97 and $95 \mathrm{~g} / \mathrm{kg}$, respectively (Fig. 2A). TAX correlated significantly with SAX, IAX and extract viscosity (Table 2).

The four cultivars also varied in contents of soluble arabinoxylans with values ranging on average between 16 $\mathrm{g} / \mathrm{kg}$ for Helltop and $22 \mathrm{~g} / \mathrm{kg}$ for Visello (Table 1). Helltop displayed lower amounts of SAX than the other three cultivars at all locations (Fig. 2B). Its values ranged between $15 \mathrm{~g} / \mathrm{kg}$ for Borwede and $18 \mathrm{~g} / \mathrm{kg}$ for Vipperow. Visello, on the other side, achieved its highest SAX content at Gülzow with an appropriate value of $25 \mathrm{~g} / \mathrm{kg}$. SAX correlated significantly with TAX, IAX and extract viscosity (Table 2).

On average, amounts of insoluble arabinoxylans ranged from $72 \mathrm{~g} / \mathrm{kg}$ for Helltop to $83 \mathrm{~g} / \mathrm{kg}$ for Minello (Table 1). Generally, Helltop exhibited lower amounts of IAX in its grains than Conduct, Minello and Visello, a tendency observed at all locations (Fig. 1C). IAX values of cultivar Helltop ranged between $66 \mathrm{~g} / \mathrm{kg}$ (Rembserhof) and $78 \mathrm{~g} / \mathrm{kg}$ (Hude) and that of Minello between $78 \mathrm{~g} / \mathrm{kg}$ (Mayen-Rosenhof) and $88 \mathrm{~g} / \mathrm{kg}$ (Rembserhof). IAX correlated significantly with TAX, SAX and extract viscosity (Table 2).

The differences in TAX, SAX and IAX between Helltop and the other three rye cultivars were all statistically significant (Table 1). Furthermore, it was important that the differences in TAX, SAX and IAX between the locations were statistically not significant (Table 3 ).

\subsection{Extract Viscosity}

As expected, the four rye cultivars varied notably in their extract viscosity (Table 1). Of the four cultivars, Visello achieved the highest extract viscosity with a mean value of $5.1 \mathrm{cSt}$. Its individual values ranged between $3.0 \mathrm{cSt}$ for the location Gülzow and $8.2 \mathrm{cSt}$ for Bornhof (Fig. 2D). The differences in extract viscosity between Visello and the other three cultivars Minello, Conduct and Helltop were all statistically significant (Table 1). Helltop exhibited the lowest extract viscosity among the four cultivars, i.e. on average (Table 1) and at all nine locations (Fig. 2D). Its individual values ranged from $1.9 \mathrm{cSt}$ (Gülzow) to $4.0 \mathrm{cSt}$ (Bornhof). The differences in extract viscosity between Helltop and the other three cultivars were all statistically significant (Table 1). The extract viscosity correlated significantly with falling numbers, TAX, SAX and IAX (Table 2).

All four cultivars revealed their lowest extract viscosity at Gülzow and their highest levels were concordantly found for Bornhof (Table 3; Fig 2D). The differences in extract viscosity between these two locations were statistically significant. In addition, Mayen-Rosenhof differed significantly in this respect from Bornhof (Table $3)$.

\subsection{Falling Numbers}

On average, Visello displayed the highest falling numbers among the four rye cultivars (Table 4). Individual values of this cultivar ranged between $105 \mathrm{~s}$ for Gülzow and $399 \mathrm{~s}$ for Bornhof. The differences in falling numbers between Visello and the other three cultivars Helltop, Conduct and Minello were all statistically significant. Helltop had the lowest falling numbers among the four cultivars with a mean value of $222 \mathrm{~s}$ and individual values ranging from $62 \mathrm{~s}$ (Gülzow) to $341 \mathrm{~s}$ (Bornhof) (Table 4), and it differed significantly in this respect from Visello, however, not from Conduct and Minello. The falling numbers were significantly correlated with the extract viscosity (Table 2).

All four cultivars exhibited their lowest falling numbers at Gülzow, while the highest values were found for Bornhof (Tables 3 and 4). The differences in falling numbers between these two locations were statistically significant. In addition, Bornhof differed significantly with respect to falling numbers from Rembserhof, Mayen-Rosenhof and Vipperow (Table 3). 


\subsection{Crude Proteins}

Helltop exhibited on average the highest crude protein contents among the four rye cultivars, and differed significantly in this respect from Visello and Minello (Table 4). Its individual values ranged between $93 \mathrm{~g} / \mathrm{kg}$ for Rembserhof and $129 \mathrm{~g} / \mathrm{kg}$ for Hude. Visello had on average the lowest amounts of crude proteins with values ranging from $80 \mathrm{~g} / \mathrm{kg}$ for Rembserhof to $120 \mathrm{~g} / \mathrm{kg}$ for Hude (Table 4). Visello differed significantly in its protein level from Helltop and Conduct. Correlations between crude proteins and all other parameters were statistically not significant (Table 2).

The four cultivars exhibited concordantly the highest crude protein contents at the location Hude, while their lowest levels were found for Rembserhof (Table 4). Differences in proteins between these last two locations were statistically significant. In addition, Hude differed significantly in this respect from Gülzow, Borwede, Hamerstorf, Mayen-Rosenhof, Vipperow and Bornhof (Table 3).

\section{Discussion}

In animal feeding the utilization of rye could be extended, provided that amounts of antinutritive substances such as arabinoxylans can be reduced (Antoniou et al., 1981; Ragaee et al., 2001). In this study, four new German winter rye cultivars were analysed for arabinoxylans comprising total, soluble and insoluble fractions, extract viscosity, falling numbers and crude protein contents - all parameters that influence the feeding quality of rye.

\subsection{Total, Soluble and Insoluble Arabinoxylans}

The procedures described in section material and methods enabled serial analyses of the three arabinoxylan fractions in rye with reliable results and a high throughput of samples (Fig. 1), a fact which is significant for breeding of rye cultivars with low arabinoxylan contents. Concerning the HPLC assay, it should be pointed out that addition of tetrahydrofuran to solvent (A) instead of methanol or acetonitrile generally used by other authors, e.g. Known and Kim (1995), lead to a better separation of arabinose and xylose as the two major sugars of arabinoxylans. Amounts of arabinoxylans including total (Bengtsson and Aman, 1990; Hansen et al., 2003; Jankiewicz and Michniewicz, 1987; Vinkx and Delcour, 1996) soluble and insoluble fractions (Antoniou et al., 1981; Fengler and Marquardt, 1988a; Salmenkallio-Marttila and Hovinen, 2005) of the four rye cultivars involved in the present work were in agreement with results of other authors. Similarly as reported elsewhere, contents of arabinoxylans including TAX, SAX and IAX were influenced by the rye genotype (Table 1; Fig. 2A-2C) (Bengtsson et al., 1992; Saastamoinen et al., 1989; Smulikowska and Nguyen, 2001). For example, total amounts of arabinoxylans accumulated in grains of the four cultivars ranged between $82 \mathrm{~g} / \mathrm{kg}$ for cultivar Helltop and $108 \mathrm{~g} / \mathrm{kg}$ for Minello when both were grown at Rembserhof (Fig. 2A).

The hybrid cultivar Helltop exhibited on average (Table 1) and at all nine locations the lowest TAX values among the four cultivars (Fig. 2A). This was an important result, since arabinoxylans bind large amounts of water and form highly viscous solutions reducing the digestion of nutrients and their absorption in the intestinal tract (Bengtsson et al., 1992; Knudsen and Laerke, 2010) associated with weight reduction in animals (Antoniou et al., 1981). Above all, water-soluble fractions of arabinoxylans cause a raise in viscosity (Antoniou et al., 1981; Bengtsson and Aman, 1990) reducing the nutrient efficiency in the diet (Misir and Marquardt, 1978; Fengler and Marquardt, 1988b). This may also be supported by the fact, that besides TAX and IAX also SAX correlated significantly with the extract viscosity (Table 2). In this context it should be mentioned that Helltop again had significantly lower amounts of SAX than Conduct, Minello and Visello, (Table 1; Fig. 2B). The SAX content in Helltop grains derived from Mayen-Rosenhof amounted only $15 \mathrm{~g} / \mathrm{kg}$, while Visello (Gülzow) was higher in its level with a value of $25 \mathrm{~g} / \mathrm{kg}$ (Fig. 2B). Similar significant differences were noticed for IAX with appropriate values ranging between $66 \mathrm{~g} / \mathrm{kg}$ for Helltop (Rembserhof) and $88 \mathrm{~g} / \mathrm{kg}$ for Conduct (Bornhof) and Minello (Rembserhof) (Fig. 2C). Among the four cultivars, Helltop again ranked on the lowest level in its IAX, i.e. on average (Table 1) and at all nine locations (Fig. 2C).

Overall, the results indicated that concentrations of arabinoxylans including all three fractions, i.e. TAX, SAX and IAX were reduced in Helltop (Table 1; Fig. 2A-2C). Accordingly, Helltop could be more suitable for animal feeding than the other three winter rye cultivars involved in the study. In this context it should be mentioned, that concentrations of all the three arabinoxylan fractions were significantly influenced by the genotype (Table 1), but not by the location (Table 3). Hence, the desired quality traits expressed in Helltop grains seem to be relatively independent from the environment.

\subsection{Extract Viscosities, Falling Numbers and Crude Protein Contents}

The extract viscosity is another important quality factor for cereals used in animal feeding (Antoniou et al., 1981; Ragaee et al., 2001). A high extract viscosity is associated with reduced nutrient utilization and weight reduction 
in animals as already mentioned (Misir and Marquardt, 1978; Fengler and Marquardt, 1988b; Ragaee et al., 2001). It was interesting therefore that the variation in extract viscosity (Table 1; Fig. 2D) among the four rye cultivars was stronger than that found for the three arabinoxylan fractions (Fig. 2A-2C). Appropriate values ranged from $1.9 \mathrm{cSt}$ for Helltop (Gülzow) to $8.2 \mathrm{cSt}$ for Visello (Bornhof). Again Helltop was outstanding and displayed the lowest extract viscosity among the four cultivars (Table 1), a tendency observed at all nine locations (Fig. 2D). On average, Helltop had two-fold lower extract viscosity than Visello. Its low extract viscosity was associated with reduced arabinoxylan contents and can be regarded as another advantage of this cultivar, especially with respect to a potential use in animal feeding. In Visello a high extract viscosity (Table 1; Fig. 2D) was combined with high amounts of SAX in its grains (Table 1; Fig. 2B). As already mentioned, the extract viscosity correlated significantly with all three arabinoxylan fractions, including SAX (Table 2). This is a result that may support the notion of Boros et al. (1993) who suggested the extract viscosity as an indirect marker for concentrations of soluble arabinoxylans accumulated in rye grains. Accordingly, measurement of extract viscosity which is relatively simple compared to HPLC assays could be used for pre-selection of genotypes with low SAX contents in rye breeding.

Falling numbers are known to be closely related with the extract viscosity (Barnard, 2001; Ragaee et al., 2001; Kucerová, 2009) and were determined therefore as another quality factor of rye. Also in the present experiments the falling numbers correlated significantly with the extract viscosity (Table 2). Falling numbers are an indirect measure of $\alpha$-amylase activity and indicate the baking quality of rye. For example, in Finland the falling number of rye flour used for bread making was mentioned to be $120 \mathrm{~s}$ (Salmenkallio-Marttila and Hovinen, 2005). Appropriate values of the four German rye cultivars ranged from $62 \mathrm{~s}$ for Helltop and Conduct both grown at Gülzow and 399 s for Visello grown at Bornhof (Table 4). With it, they varied stronger and were higher in their maximum than those of the rye cultivars grown in Finland (Salmenkallio-Marttila and Hovine, 2005). Visello had on average the highest falling numbers and differed significantly in this respect from Conduct, Minello and Helltop which again ranked on the lowest level among the four rye cultivars (Table 4).

Apart from crude fibre, proteins are major quality factors of feeds, since they are needed for the supply of animals with essential amino acids (González-Martin et al., 2006). The crude protein contents ranged between $80 \mathrm{~g} / \mathrm{kg}$ for Visello (Rembserhof) and $129 \mathrm{~g} / \mathrm{kg}$ for Helltop (Hude). It was interesting, that Helltop achieved the highest level in proteins among the four cultivars (Table 4). This tendency was in contrast to those found for its extract viscosity, falling numbers, IAX, SAX and TAX contents which all ranked on a low level in this cultivar. Doubtless, such high amounts of crude proteins can be seen as another advantage of the hybrid cultivar Helltop with respect to a potential use in animal feeding. It should be mentioned in this context that crude protein contents were influenced by the rye genotype and the location, similarly as it was observed for the extract viscosity and falling numbers (Tables $1,3,4$ ).

\section{Conclusions}

In order to widen the use of rye in animal feeding, it is necessary to find genotypes with reduced arabinoxylan contents and low extract viscosity. The anthocyanin free hybrid cultivar Helltop may fulfil these requirements, since it combined relatively low amounts of TAX, SAX and IAX with low extract viscosities and falling numbers, but high crude protein contents. Such combination in quality traits might be optimal with respect to a potential use as component in animal diet. Apart from the last aspect, Helltop could be an interesting candidate for involvement in breeding of new rye cultivars with low arabinoxylan contents and extract viscosity. Successful breeding efforts in this direction may be helpful to increase the field of using rye for different purposes.

\section{Acknowledgements}

We thank C. Leesch and M. Jennerjahn for technical assistance.

\section{References}

Allen, T. (2002). The world supply of fall (winder) rye. In: Winter cereal production. (Ed D. B. Fowler) University of Saskatchewan, Saskatoon, Canada. http://www.usask.ca/agriculture/plantsci/winter_cereals/ winter_rye/production1.php

Anonymus (2011). Cultivation and marketing of rye - Rye Belt: Feeding. http://www.ryebelt.com/660.html?\&L=1

Antoniou, T., Marquardt, R. R. \& Cansfield, P. E. (1981). Isolation, partial characterization, and antinutritional activity of a factor (Pentosans) in rye grain. Journal of Agricultural and Food Chemistry, 29, 1240-1247. 
Barnard, A. (2001). Genetic diversity of South African winter wheat cultivars in relation to preharvest sprouting and falling number. Euphytica, 119, 109-112.

Bengtsson, S. \& Aman, P. (1990). Isolation and chemical characterization of water-soluble arabinoxylans in rye grain. Carbohydrate Polymers, 12, 267-277.

Bengtsson, S., Andersson, R., Westerlund, E. \& Aman, P. (1992). Content, structure and viscosity of soluble arabinoxylans in rye grain from several countries. Journal of the Science of Food and Agriculture, 58, 331-337.

Bigge, J. C., Patel, T. P., Bruce, J. A., Goulding, P. N., Charles, S. M. \& Parekh, R. B. (1995). Nonselective and efficient fluorescent labeling of glycans using 2-amino benzamide and anthranilic acid. Analytical Biochemistry, 230, 229-238.

Boros, D., Marquardt, R. R., Slominski, B. A. \& Guenter, W. (1993). Extract viscosity as an indirect assay for water-soluble pentosan content in rye. Cereal Chemistry, 70, 575-580.

Bushuk, W. (2001). Rye production and uses worldwide. Cereal Foods World, 46, 70-73.

Dongowski, G. (2007). Interaction between dietary fibre-rich preparations and glycoconjugated bile acids in vitro. Food Chemistry, 104, 390-397.

Fengler, A. I. \& Marquardt, R. R. (1988a). Water soluble pentosans from Rye: I. Isolation, partial purification and characterization. Cereal Chemistry, 65, 291-297.

Fengler, A. I. \& Marquardt, R. R. (1988b). Water soluble pentosans from rye: II. Effects on rate of dialysis and on the retention of nutrients by the chick. Cereal Chemistry, 65, 298-302.

Garcia A. L., Otto B., Reich S. C., Weickert M. O., Steiniger J., Machowetz A. et al. (2007). Arabinoxylan consumption decreases postprandial serum glucose, serum insulin and plasma total ghrelin response in subjects with impaired glucose tolerance. European Journal of Clinical Nutrition, 61, 334-341.

González-Martín, I., Àlvarez-García, N. \& Hernández-Andaluz, J. L. (2006). Instantaneous determination of crude proteins, fat and fibre in animal feeds using near infrared reflectance spectroscopy technology and a remote reflectance fibreoptic probe. Animal Feed Science and Techology, 128, 165-171.

Hansen, H. B., Rasmussen, C. V., Knudsen, K. E. B. \& Hansen, A. (2003). Effect of genotype and harvest year on content and composition of dietary fibre in rye (Secale cereale L.) grain. Journal of the Science of Food and Agriculture, 83, 76-85.

Jankiewicz, M. \& Michniewicz, J. (1987). The effect of soluble pentosans isolated from rye grain on staling of bread. Food Chemistry, 25, 241-249.

Knudsen, K. E. B. \& Laerke, H. N. (2010). Rye arabinoxylans: Molecular structure, physicochemical properties and physiological effects in the gastrointestinal tract. Cereal Chemistry, 87, 353-362.

Kucerová J. (2009) Effect of location and year on technological quality and pentosan content in rye. Czech Journal of Food Science, 6, 418-424.

Known, H. J. \& Kim J. (1995). High-performance liquid-chromatography of monosaccharides and oligosaccharides derivatized with p-aminobenzoic ethyl-ester on a C-18-bonded silica column. Journal of Liquid Chromatography, 18, 1437-1449.

Linko, A. M. \& Adlercreutz H. (2005). Whole-grain rye and wheat alkylresorcinols are incorporated into human erythrocyte membranes. British Journal of Nutrition, 93, 11-13.

Misir R. \& Marquardt R. R. (1978). Factors affecting rye (Secale cerale L.) utilization in growing chicks. IV. The influence of autoclave treatment, pelleting, water extraction and penicillin supplementation. Canadian Journal of Animal Science, 58, 731-742.

Nyström, L, Lampi, A. M., Andersson, A. A. M., Kamal-Eldin, A., Gebruers, K., Courtin, C. M. et al. (2008). Phytochemicals and dietary fibre components in rye varieties in the healthgrain diversity screen. Journal of Agricultural and Food Chemistry, 56, 9758-9766.

Ragaee, S. M., Campbell, G. J., Scoles, G. J., McLeod J. G. \& Tyler R. T. (2001). Studies on rye (Secale cereale L.) lines exhibiting a range of extract viscosities. 2. Rheological and baking characteristics of rye and rye/wheat blends and feeding value for chicks of wholemeals and breads. Journal of Agricultural and Food Chemistry, 49, 2446-2453.

Saastamoinen, M, Plaami, S. \& Kumpulainen, J. (1989). Pentosan and B-glucan content of Finnish winter rye varieties as compared with rye of six other countries. Journal of Cereal Science, 10, 199-207. 
Salmenkallio-Marttila, M. \& Hovinen, S. (2005). Enzyme activities, dietary fibre components and rheological properties of wholemeal flours from rye cultivars grown in Finland. Journal of the Science of Food and Agriculture, 85, 1350-1356.

Smulikowska, S. \& Nguyen, V. C. (2001). A note on variability of water extract viscosity of rye grain from north-east regions of Poland. Journal of Animal and Feed Science, 10, 687-693.

Vinkx, C. J. A. \& Delcour, J. A. (1996). Rye (Secale cereale L.) arabinoxylans: A critical review. Journal of Cereal Science, 24, 1-14.

Table 1. Amounts of total, soluble and insoluble arabinoxylans as well as extract viscosity of the four rye cultivars grown at nine locations (Means and standard error; $\mathrm{n}=9$ locations). Harvest 2010

\begin{tabular}{|c|c|c|c|c|}
\hline \multirow[t]{2}{*}{ Cultivar } & \multicolumn{3}{|c|}{ Arabinoxylans (g/kg) } & \multirow{2}{*}{$\begin{array}{l}\text { Extract viscosity } \\
\text { (cSt) }\end{array}$} \\
\hline & Total & Soluble & Insoluble & \\
\hline \multicolumn{5}{|l|}{ Helltop } \\
\hline Mean & $88.5^{\mathrm{a}}$ & $16.2^{\mathrm{a}}$ & $72.3^{\mathrm{a}}$ & $2.61^{\mathrm{a}}$ \\
\hline Error & 1.3 & 0.4 & 1.2 & 0.21 \\
\hline \multicolumn{5}{|l|}{ Conduct } \\
\hline Mean & $101.4^{\mathrm{b}}$ & $20.0^{\mathrm{b}}$ & $81.4^{\mathrm{b}}$ & $3.85^{\mathrm{b}}$ \\
\hline Error & 1.4 & 0.7 & 1.4 & 0.29 \\
\hline \multicolumn{5}{|l|}{ Minello } \\
\hline Mean & $103.1^{\mathrm{b}}$ & $20.4^{\mathrm{bc}}$ & $82.7^{\mathrm{b}}$ & $4.41^{b}$ \\
\hline Error & 1.2 & 0.6 & 1.0 & 0.49 \\
\hline \multicolumn{5}{|l|}{ Visello } \\
\hline Mean & $100.6^{\mathrm{b}}$ & $21.7^{\mathrm{c}}$ & $78.9^{\mathrm{b}}$ & $5.14^{\mathrm{c}}$ \\
\hline Error & 1.2 & 0.5 & 1.2 & 0.54 \\
\hline
\end{tabular}

Cultivar means followed by different letters within the same column differ significantly at $\mathrm{P}<0.05$

Table 2. Correlations between quality parameters of the four rye cultivars grown at nine locations. Harvest 2010

\begin{tabular}{|c|c|c|c|c|c|c|}
\hline \multirow[t]{2}{*}{ Parameter } & \multirow{2}{*}{$\begin{array}{l}\text { Protein } \\
\text { contents }\end{array}$} & \multirow{2}{*}{$\begin{array}{l}\text { Falling } \\
\text { numbers }\end{array}$} & \multirow{2}{*}{$\begin{array}{l}\text { Extract } \\
\text { viscosity }\end{array}$} & \multicolumn{3}{|c|}{ Arabinoxylans } \\
\hline & & & & Total & Soluble & Insoluble \\
\hline Protein content & 1.00 & & & & & \\
\hline Falling number & 0.16 & 1.00 & & & & \\
\hline Extract viscosity & -0.08 & $0.70^{*}$ & 1.00 & & & \\
\hline Total arabinoxylans & -0.09 & 0.20 & $0.56^{*}$ & 1.00 & & \\
\hline Soluble arabinoxylans & -0.19 & -0.15 & $0.43^{*}$ & $0.73^{*}$ & 1.00 & \\
\hline $\begin{array}{l}\text { Insoluble } \\
\text { arabinoxylans }\end{array}$ & -0.03 & 0.33 & $0.52 *$ & $0.94 *$ & $0.45^{*}$ & 1.00 \\
\hline
\end{tabular}

* Significant at $\mathrm{P} \leq 0.01 ; \mathrm{n}=36$ 
Table 3. Amounts of total, soluble and insoluble arabinoxylans as well as extract viscosity, falling numbers and crude protein contents of the four rye cultivars grown at nine locations (Means and standard error; $n=4$ cultivars per location). Harvest 2010

\begin{tabular}{|c|c|c|c|c|c|c|}
\hline \multirow[t]{2}{*}{ Location } & \multicolumn{2}{|c|}{ Arabinoxylans $(\mathrm{g} / \mathrm{kg})$} & \multirow[b]{2}{*}{ Insoluble } & \multirow{2}{*}{$\begin{array}{l}\text { Extract } \\
\text { viscosity } \\
(\mathrm{cSt}) \\
\end{array}$} & \multirow{2}{*}{$\begin{array}{l}\text { Falling } \\
\text { numbers } \\
\text { (s) }\end{array}$} & \multirow{2}{*}{$\begin{array}{l}\text { Crude } \\
\text { proteins } \\
(\mathrm{g} / \mathrm{kg}) \\
\end{array}$} \\
\hline & Total & Soluble & & & & \\
\hline \multicolumn{7}{|l|}{ Gülzow } \\
\hline Mean & $97.2^{\mathrm{a}}$ & $22.0^{\mathrm{a}}$ & $75.1^{\mathrm{a}}$ & $2.52^{\mathrm{b}}$ & $74^{\mathrm{e}}$ & $100.5^{\mathrm{bcd}}$ \\
\hline Error & 4.3 & 1.7 & 2.9 & 0.22 & 10 & 2.6 \\
\hline \multicolumn{7}{|l|}{ Neuhof } \\
\hline Mean & $97.5^{\mathrm{a}}$ & $18.6^{\mathrm{a}}$ & $78.8^{\mathrm{a}}$ & $4.68^{\mathrm{ab}}$ & $302^{\mathrm{ab}}$ & $114.0^{\mathrm{ab}}$ \\
\hline Error & 3.3 & 0.6 & 2.8 & 0.68 & 19 & 4.1 \\
\hline \multicolumn{7}{|l|}{ Borwede } \\
\hline Mean & $98.9^{\mathrm{a}}$ & $18.3^{\mathrm{a}}$ & $80.6^{\mathrm{a}}$ & $3.79^{\mathrm{ab}}$ & $301^{\mathrm{ab}}$ & $92.9^{\mathrm{cd}}$ \\
\hline Error & 3.4 & 1.4 & 2.4 & 0.57 & 14 & 3.2 \\
\hline \multicolumn{7}{|l|}{ Hude } \\
\hline Mean & $102.0^{\mathrm{a}}$ & $20.0^{\mathrm{a}}$ & $81.9^{\mathrm{a}}$ & $4.51^{\mathrm{ab}}$ & $341^{\mathrm{a}}$ & $123.1^{\mathrm{a}}$ \\
\hline Error & 2.8 & 1.2 & 1.6 & 0.66 & 17 & 3.1 \\
\hline \multicolumn{7}{|c|}{ Hamerstorf } \\
\hline Mean & $98.1^{\mathrm{a}}$ & $19.5^{\mathrm{a}}$ & $78.5^{\mathrm{a}}$ & $4.55^{\mathrm{ab}}$ & $294^{\mathrm{ab}}$ & $100.6^{\mathrm{bcd}}$ \\
\hline Error & 3.2 & 1.4 & 1.8 & 0.68 & 19 & 2.6 \\
\hline \multicolumn{7}{|c|}{ Rembserhof } \\
\hline Mean & $98.0^{\mathrm{a}}$ & $19.0^{\mathrm{a}}$ & $79.1^{\mathrm{a}}$ & $3.43^{\mathrm{ab}}$ & $195^{\mathrm{cd}}$ & $86.9^{\mathrm{d}}$ \\
\hline Error & 5.7 & 1.1 & 4.6 & 0.39 & 23 & 2.6 \\
\hline \multicolumn{7}{|c|}{ Mayen-Rosenhof } \\
\hline Mean & $92.5^{\mathrm{a}}$ & $17.9^{\mathrm{a}}$ & $74.5^{\mathrm{a}}$ & $2.81^{\mathrm{b}}$ & $223^{\mathrm{bc}}$ & $99.7^{\mathrm{bcd}}$ \\
\hline Error & 2.2 & 1.2 & 1.3 & 0.31 & 17 & 2.5 \\
\hline \multicolumn{7}{|l|}{ Vipperow } \\
\hline Mean & $101.0^{\mathrm{a}}$ & $21.5^{\mathrm{a}}$ & $79.5^{\mathrm{a}}$ & $3.49^{\mathrm{ab}}$ & $122^{\mathrm{de}}$ & $102.4^{\mathrm{bc}}$ \\
\hline Error & 3.8 & 1.4 & 2.5 & 0.42 & 28 & 3.2 \\
\hline \multicolumn{7}{|l|}{ Bornhof } \\
\hline Mean & $100.6^{\mathrm{a}}$ & $19.6^{\mathrm{a}}$ & $81.0^{\mathrm{a}}$ & $6.23^{\mathrm{a}}$ & $365^{\mathrm{a}}$ & $99.3^{\mathrm{bcd}}$ \\
\hline Error & 3.0 & 1.4 & 3.1 & 0.98 & 12 & 4.1 \\
\hline
\end{tabular}

Location means followed by different letters within the same column differ significantly at $\mathrm{P}<0.05$

Table 4. Falling numbers and crude protein contents of the four rye cultivars grown at nine locations. Harvest 2010

\begin{tabular}{|c|c|c|c|c|c|c|c|c|}
\hline \multirow{2}{*}{ Location } & \multicolumn{4}{|c|}{ Falling numbers (s) } & \multicolumn{4}{|c|}{ Crude proteins $(\mathrm{g} / \mathrm{kg})$} \\
\hline & Helltop & Conduct & Minello & Visello & Helltop & Conduct & Minello & Visello \\
\hline Gülzow & 62 & 62 & 69 & 105 & 104.8 & 103.5 & 100.5 & 93.1 \\
\hline Neuhof & 257 & 294 & 308 & 351 & 121.2 & 120.5 & 109.4 & 104.9 \\
\hline Borwede & 275 & 282 & 314 & 335 & 100.9 & 93.9 & 91.4 & 85.4 \\
\hline Hude & 313 & 331 & 391 & 329 & 129.1 & 127.2 & 116.0 & 120.0 \\
\hline Hamerstorf & 300 & 262 & 269 & 345 & 101.9 & 107.5 & 96.2 & 96.8 \\
\hline Rembserhof & 171 & 208 & 148 & 252 & 92.5 & 89.1 & 85.8 & 80.1 \\
\hline Mayen-Rosenhof & 210 & 187 & 226 & 269 & 103.1 & 104.5 & 97.1 & 93.9 \\
\hline Vipperow & 71 & 78 & 153 & 187 & 108.4 & 106.8 & 99.5 & 94.9 \\
\hline Bornhof & 341 & 357 & 362 & 399 & 104.5 & 107.9 & 91.5 & 93.2 \\
\hline Mean & $222^{\mathrm{a}}$ & $229^{\mathrm{a}}$ & $249^{\mathrm{a}}$ & $286^{\mathrm{b}}$ & $107.4^{\mathrm{a}}$ & $106.8^{\mathrm{a}}$ & $98.6^{\mathrm{b}}$ & $95.8^{\mathrm{b}}-\mathrm{r} \cdot \mathrm{r} \cdot \mathrm{c}$ \\
\hline Error & 34 & 35 & 36 & 31 & 3.7 & 3.9 & 3.1 & 3.8 \\
\hline
\end{tabular}

Cultivar means followed by different letters within the same line differ significantly at $\mathrm{P}<0.05$ 


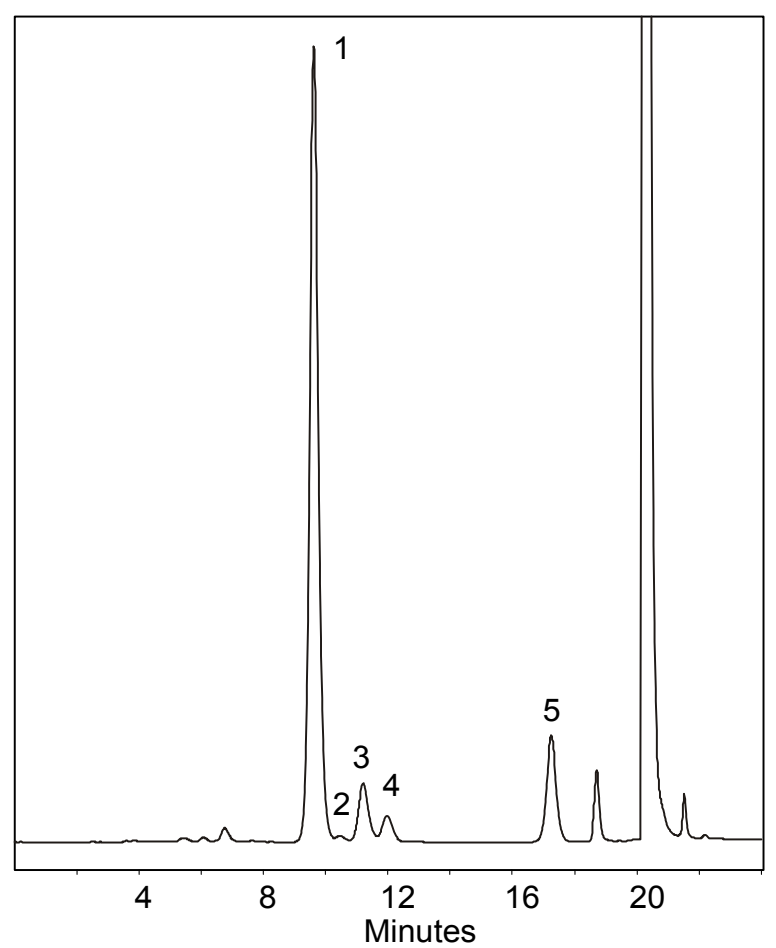

Figure 1. HPLC chromatogram for total arabinoxylans present in grains of cultivar Helltop grown at Hude in 2010. Peak ID: $1=$ Glucose, $2=$ Galactose, $3=$ Xylose, $4=$ Arabinose, $5=$ ISTD

$2 \mathbf{A}$

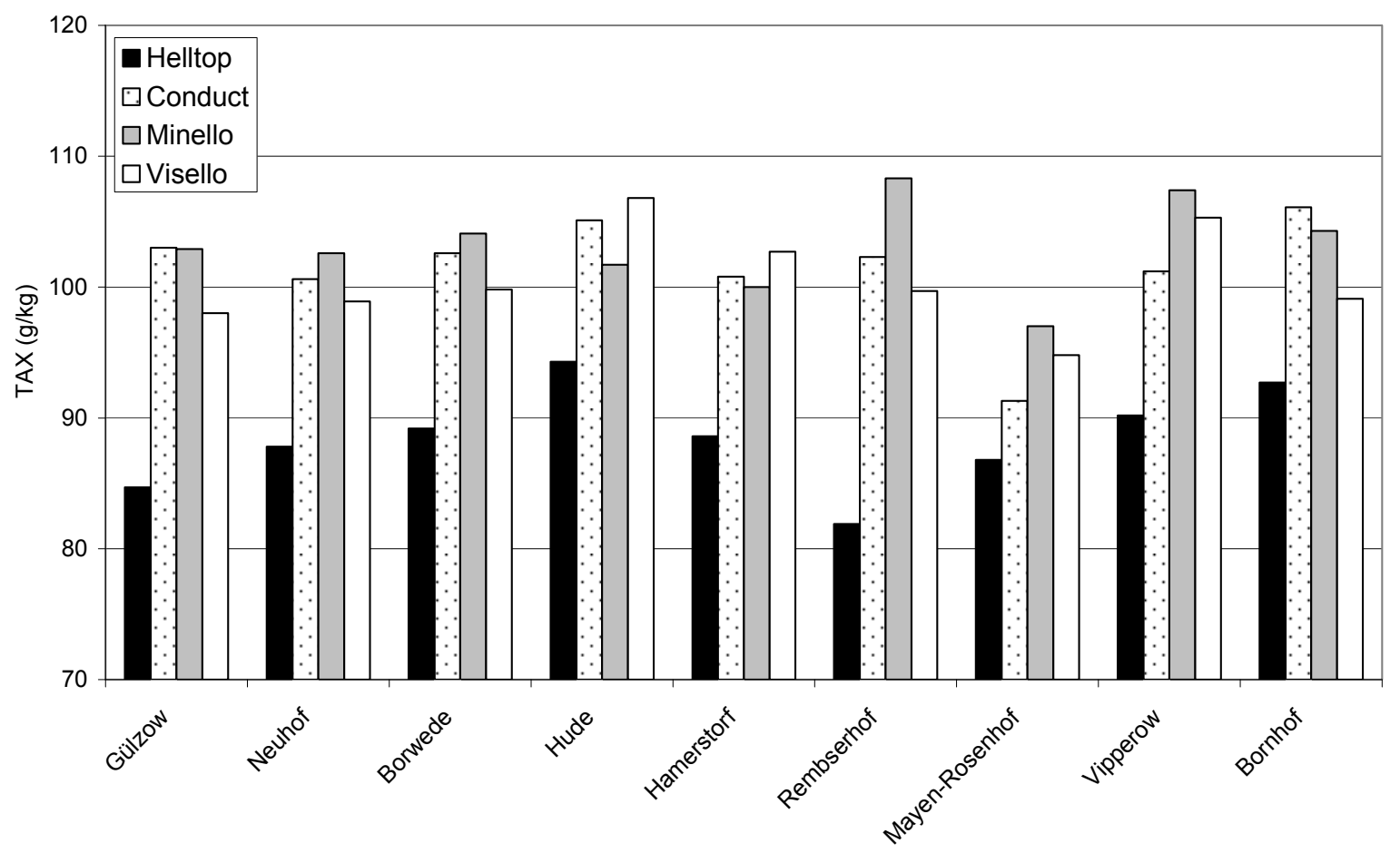


$2 B$

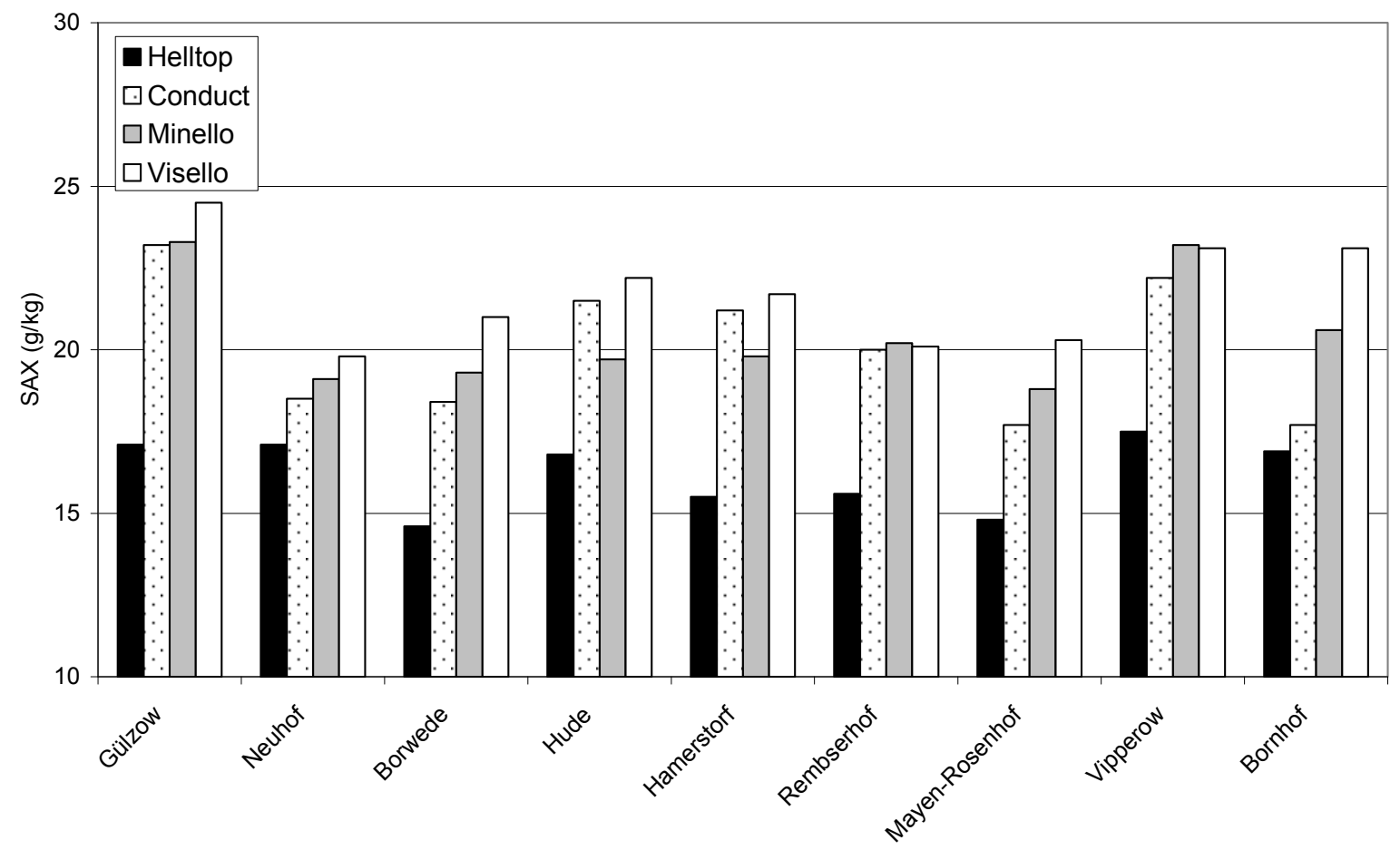

$2 \mathrm{C}$

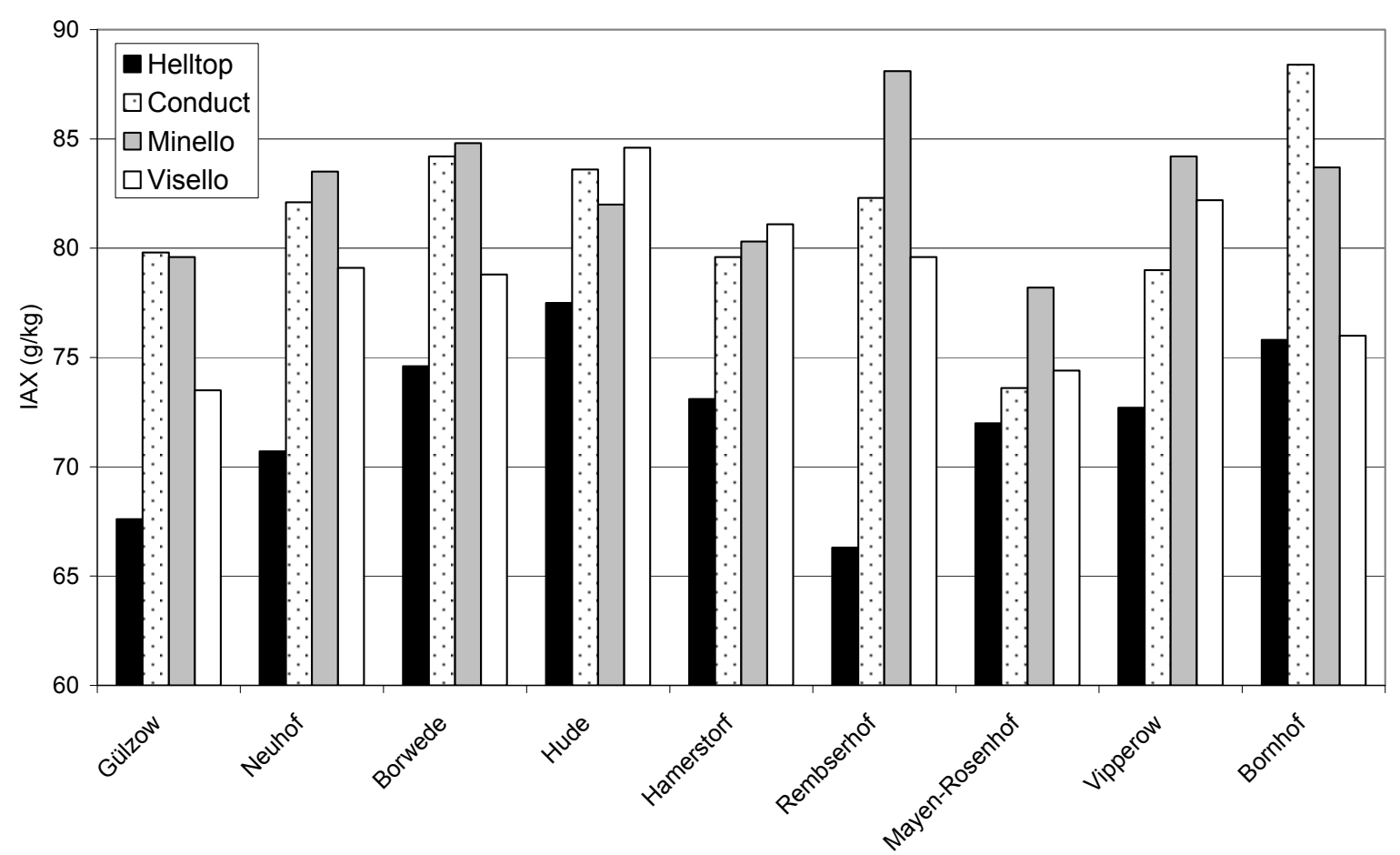




\section{D}

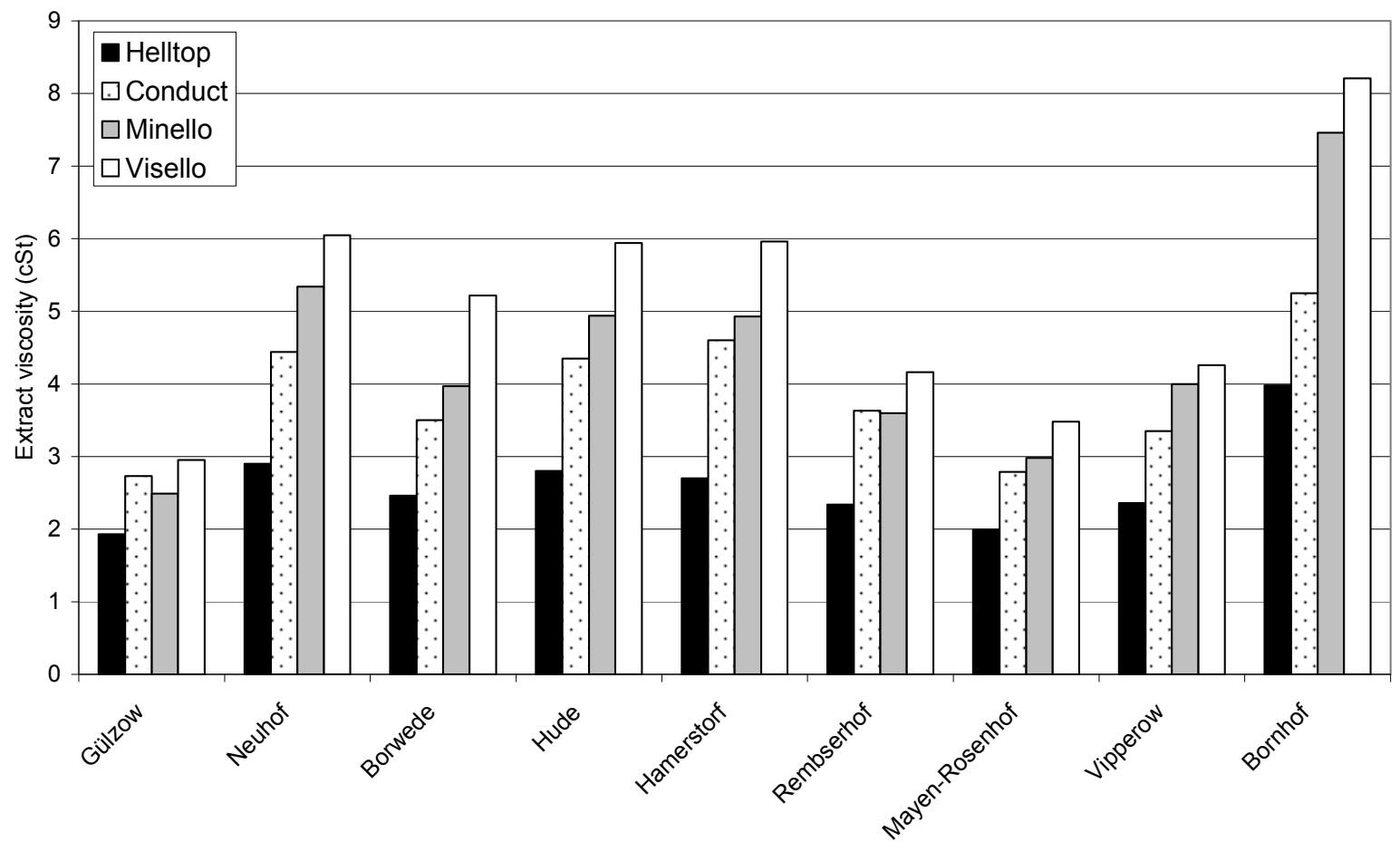

Figure 2. Arabinoxylan contents including total (A), water-soluble (B) and insoluble fractions (C) as well as extract viscosity (D) of the four rye cultivars grown at nine locations in 2010 